\title{
THE EVOLUTION OF LEADERSHIP IN CHINA
}

\section{R RAVI MOHAN*}

Assistant Professor, Department of Management Studies, Bharath Institute of Higher Education and Research (Biher), Chennai

ABSTRACT
Transformational administration pulled in a lot of insightful consideration in the previous couple of decades.
This study is intended to build up a compelling transformational authority display so as to mechanism in the Chinese
setting. A representation is planned toward clear up interceding impacts of belief and agreement resting on the
association flanked by transformational administration in addition to feasibility. The representation give another point of
view on administration in Chinese setting so as to is overlooked in the West initiative writing. It similarly offer a clear
comprehension of most excellent transformation authority hone joins by means of customary Chinese astuteness in the
direction of make a better showing with regards to in representing the pioneer supporter flow in contemporary Chinese
society.
KEYWORDS: Chinese, Custom, Association

Received: Feb 05, 2019; Accepted: Feb 25, 2019; Published: Mar 25, 2019; Paper Id.: IJBMRJUN20199

\section{INTRODUCTION}

Transformational initiative hypothesis has pulled in a lot of academic consideration from crosswise over orders. This hypothesis started by means of the labor of Burns in addition to afterward be shaped by Bass and other. ${ }^{1}$ The significant reason of transform management hypothesis be the manager capacity in the direction of propel supporters in the direction of finish additional than they required in the direction of performance ${ }^{2}$ .Transformation pioneers rouse supporters in the direction of rise above their possess exacting personality wellbeing intended for the benefit on association and are fit for having a significant and uncommon shock on their devotee. ${ }^{3}$

\section{REVIEW OF LITERATURE}

This article critically reviews the literature on leaders and foreign policy and considers the possibility that leaders might matter more in the case of Chinese foreign policy. In addition, it examines some of the, often erroneous, judgments that have been made about the power of Chinese policymakers, focusing on uncertainties relating to the power of Chinese President Xi Jinping, whose actual power continues to be a subject of considerable debate. Furthermore, it recommends some metrics that might be used to more systematically evaluate the power of Chinese elites. Beyond this, it summarizes the articles in the special issue and what they say about the issue of China's leadership transition and Chinese foreign policy. It concludes with some theoretical and policy conclusions and identifies some avenues for further research. ${ }^{4}$

\section{RESEARCH METHODOLOGY}

Descriptive research includes surveys and fact-finding enquires of different kinds. The major purpose of descriptive research is description of the state of affairs as it exists at present. The main characteristic of this method is that the researcher has no control over the variables; he can only report what has happened or what is happening. 
This project involves descriptive research for data collection. ${ }^{5}$

\section{Research Design}

Research Design is the conceptual structure within which research is conducted. It constitutes the blueprint for collection, measurement, \& analysis of the data. The design used for carrying out this research is exploratory \& experience based. ${ }^{6}$

The researcher intends to carry out primary and secondary research, carry out focus interviews and group discussions which would help me to gather fresh data which can be analyzed with the past data to seek the existing trends. The research instrument used for collecting data in this study is a structured questionnaire, a tool for gathering data.

\section{Target Respondents}

The sample of 130 Chinese English speaking citizens in Chennai city was taken as sample for this study.

\section{RESEARCH DESIGN}

Research Design is the conceptual structure within which research is conducted. It constitutes the blueprint for collection, measurement, \& analysis of the data. The design used for carrying out this research is exploratory \& experience

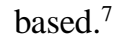

The researcher intends to collect primary data, which can be analyzed with the past data to seek the existing views in China on its leadership.

\section{DATA COLLECTION}

\subsection{Primary Data}

Primary data is the first and it is collected from the Chinese English speaking citizens in Chennai. The collection of data from the respondents was done through a structured questionnaire In English.

\section{SAMPLING METHODS}

Collecting data about each plus every unit of the population is called census method. The approach, where only a few units of inhabitants under study are considered for examination is called sampling method. There are two main categories.

- Probability sampling.

- Non-probability sampling. ${ }^{8}$

The sampling method adopted for the study is two-stage random sampling method was used. First, contact details of all eligible Chinese English speaking citizens in Chennai city was collected and from this, 130 respondents were randomly selected and were administered a structured questionnaire which was filled by the respondents in English.

\section{TOOLS FOR ANALYSIS}

- Simple percentage analysis.

- Weighted Average Method. 
- Chi-Square Test.

\section{CONCLUSIONS}

Let us compare China with the USA for a moment. China is a continent-wide country whose land area is eerily close in terms of square miles to that of the United States. Look at a map and imagine that China's western border was bounded by sea and the analogy becomes even more eerie. For the Rockies read the Himalayas. For the heavily industrialised north-east of the United States, read the heavily industrialised north-east of China, including Manchuria. For Washington's location read Beijing. For Florida read Guangdong province in the south-east. The Yangtze may flow westeast while the Mississippi flows north-south, but each is an enormous river that bisects its country. And for Shanghai read New York. The similarities stop here. ${ }^{9}$

Based on this study, it was found that the Chinese model of providing the facilities which were available in metro cities in villages, prevented the migration of a large number of families to metro cities. This helped the Chinese to prevent the over population of their cities which was already heavily polluted from becoming worse.

They also felt that the Chinese model of adopting the best of both Capitalism and Communism was helpful in creating the powerful China of today. The use of technology to enhance their production capabilities and export their products all over the world was made possible through strict enforcement of rules to prevent crime and other undesirable activities and control over their population has helped them become a super power not only in Asia but also in other parts of the world. The result today is that the Chinese product are used by the entire population of the world and hence this made the people of China prosperous and wealthy. All this would not have been possible but for the able leaders of China who have helped China become the super power of the world. ${ }^{10}$

Under the leadership of Jiang Zemin (1993-2003), China experienced substantial developmental growth with reforms, saw the peaceful return of Hong Kong from the United Kingdom and Macau from Portugal, and improved its relations with the outside world while the Communist Party maintained its tight control over the government. Jiang was criticized for being too concerned about his personal image at home, and too conciliatory towards Russia and the United States abroad. ${ }^{11}$

Under the leadership of $\mathrm{Hu}$ Jintao,(2003-2013), long having been anointed by Deng as Jiang's successor, took over the presidency in 2003, and also held the offices of General Secretary of the Communist Party and Chairman of the Central Military Commission. Hu presided over nearly a decade of consistent economic growth and a relatively smooth recovery from the Global Financial Crisis. China emerged as a major world power during Hu's term, as China began taking on a more prominent role globally, such as at the G20 and global efforts at combating climate change. Hu's chief domestic focus was building a more egalitarian society focused on improving living standards for disadvantaged populations.[6] During Hu's tenure, China's influence in Africa, Latin America, and other developing countries increased. ${ }^{12}$

Under the leadership of Xi Jinping(2013-2018), became President in 2013, and also held the offices of General Secretary of the Communist Party and Chairman of the Central Military Commission. Xi increased the profile of the office of president in foreign affairs, for example receiving other heads of state during the 2015 China Victory Day Parade, going on high-profile visits to the United Kingdom and the United States, and making an important address at the Global Economic Forum in Davos, Switzerland. Term limits for the president were removed in $2018 .{ }^{13}$ 
He has been front and centre of China's push to cement its position as a superpower, while also launching crackdowns on corruption and dissent. A consummate political chess player who has cultivated an enigmatic strongman image, the leader of the ruling Chinese Communist Party has rapidly consolidated power, having his ideas mentioned by name in the constitution - an honour that had been reserved only to Mao Zedong until now. The "Xi Jinping Thought" means that any challenge to the president will now be seen as a threat to Communist Party rule. A seven-man leadership committee unveiled in October 2017 included no obvious heir, raising the prospect that Mr Xi intended to govern beyond the next five years. The Communist Party has now confirmed that aim, with a proposal to remove a clause in the constitution that limits the presidency to two terms.

\section{REFERENCES}

1. Social identity and charismatic leadership attribution: why do they think he's fabulous when we know he's not? A Verhagen 2014 - openresearch-rrepository.anu. .edu.au

2. Embedded autonomy: States and industrial transformation, PB Evans - 2012.

3. Recollections of a Labour Pioneer, FW Soutter - 2018.

4. The People's Republic of China leadership transition and its external relations: still searching for definitive answers - JeanMarc F. Blanchard, Journal of Chinese Political Science, March 2015, Volume 20, Issue 1, pp 1-16.

5. Business research Methods, WG Zikmund, BJ Babin, JC Carr, M.Griffin-013.

6. Case study research and applications: Design and methods, RK Yin - 2017 Sage publications.

7. Case study research and applications: Design and methods, RK Yin - 2017 - Sage publications.

8. Analyzing qualitative data: Systematic approaches, HR Bernard, A Wutich, GW Ryan - 2016.

9. True Size of Africa: Continent is as big as China, India,US and most of .../https://www.daily. .co.uk/Oct 5,2013.

10. Urbanization in China and the coordinated development model-The case of Chengdu A Chen, J Gao - The Social Science Journal, 2011 - Elsevier.

11. The Ashgate research companion to Chinese foreign policy E Kavalski - 2016 - books.google.com.

12. Mao Zedong and Xi Jinping: A Trait Analysis D Douglas - 2017.

13. China in the 21st Century: What Everyone Needs to Know®JN Wasserstrom, ME.Cunningham - 2018 